\title{
Analisis City Branding Kabupaten Sukoharjo Sebagai Kota Jamu: Pendekatan Persepsi Brand Box Model
}

\author{
Lilik Wahyudi, Sarjiyanto ${ }^{*}$, Pram Suryanadi \\ Fakultas Ekonomi dan Bisnis, Universitas Sebelas Maret, Surakarta \\ *masyanto@staff.uns.ac.id
}

\begin{abstract}
This study aims to assess the model city branding based on superior product through perception approach of brand box models. This study is conducted to explore consumer perceptions of a traditional medicinal herbal drink products"jamu" in order to build a city branding by medicinal product as region superior product as part of the local communities empowerment. Development of city branding is conducted by the exploration of perception approach of brand box models. Exploration of perception is conducted by ethnographic methods and netnographic methods in several target areas of research. The area regions of this research are Soloraya region (subosukowonosraten) as the market potential of a city branding Sukoharjo. This results show : 1) there is a strong influence of the perception of the city image on overall value; 2) there is the strong influence of overall value on the intention to recommend and intention to visit
\end{abstract}
Keywords : Brandbox Models, City Branding, Traditional Medicinal Herbal Drink Products

\section{PENDAHULUAN}

Saat ini beberapa kota berupaya memperkenalkan kekhasan mereka dengan menonjolkan beberapa aspek yang dianggap khas atau unik. Kabupaten sukoharjo sebagai salah satu kabupaten di Jawa Tengah mencoba membuat branding kabupaten sebagai kabupaten jamu. Penetapan Kabupaten Sukoharjo sebagai kabupaten jamu di lakukan pada Tahun 2015. Konsep yang di bangun adalah menonjolkan wisata jamu sebagai ikon kabupaten tersebut. Berbagai upaya di lakukan oleh Kabupaten Sukoharjo untuk menonjolkan posisinya sebagai kota wisata jamu melalui berbagai event termasuk pemecahan rekor muri minum jamu terbanyak pada Tahun 2016.

Pada kasus branding Kabupaten Sukoharjo sebagai destinasi wisata jamu, simbolisme dari branding yang dilakukan baru dapat terlihat beberapa tahun setelah berbagai event/kegiatan dilakukan. Proses simbolisme yang terbentuk membutuhkan waktu yang cukup lama. Berbagai unsur mulai dari pelaku usaha, masyarakat, pemerintah dan masyarakat diluar Kabupaten Sukoharjo perlu di teliti. Berkaitan dengan bagaimana perubahan persepsi mereka dari pandangan Kabupaten Sukoharjo menjadi kabupaten dengan destinasi wisata jamu yang berskala nasional. Efektivitas city branding dilihat dari perubahan persepsi masyarakat setelah di lakukan berbagai upaya untuk meningkatkan citra kota tersebut di masyarakat luas.

Pendekatan city branding dalam menggunakan evaluasi berdasarkan realitas, konsep dan simbolisme pada branding. Simbolisme menjadi penekanan utama dalam kajian riset ini. Simbolisme dimulai dari pemahaman simbolisme pada konsumen, calon konsumen dan kemudian di lanjutkan dengan pemahaman simbolisme pada masyarakat secara luas. 
Penelitian ini memfokuskan kajian pada bagaimana perubahan persepsi masyarakat diluar wilayah Kabupaten Sukoharjo terhadap branding destinasi wisata jamu. Apakah branding yang di lakukan menumbuhkan minat masyarakat luar untuk berkunjung ke destinasi wisata jamu Kabupaten Sukoharjo.

\section{Pendekatan Brand-Box Model}

Konsep city branding di bangun atas empat elemen penting meliputi elemen fungsional, simbolik, status dan elemen budaya. Unsur fungsional dari city branding merupakan produk/layanan yang menjadi ciri khas dari kota tersebut. Elemen simbolik merupakan unsur persepsi/citra yang akan dibentuk terkait dengan produk. Misalkan kota yogyakarta, unsur fungsionalnya terkait dengan layanan pendidikan yang ditunjukkan dengan banyaknya perguruan tinggi yang ada di Yogyakarta, maka simbolisme yang di pakai adalah Yogyakarta sebagai kota pendidikan. Unsur fungsional produk merupakan aspek utama yang ingin di tonjolkan melalui bentuk simbolisme tertentu. Caldwell dan Freire (2004) menyebutkan unsur utama dalam model merek meliputi dua hal yaitu unsur fungsional dan unsur representasional (image). Unsur fungsional berdasar fungsi merek tersebut untuk memenuhi kebutuhan konsumen. Sedangkan unsur representasional mencerminkan karakteristik ekspresi nilai dari merek tersebut. Unsur fungsional pada kasus city branding Kabupaten Sukoharjo adalah wisata jamu. Produk jamu yang dijadikan sebagai icon kota. Unsur representasional ini meliputi simbol, status dan budaya yang ditawarkan oleh sukoharjo. Gambar brand-box model kota Sukoharjo dapat dilihat pada gambar 1 berikut ini:

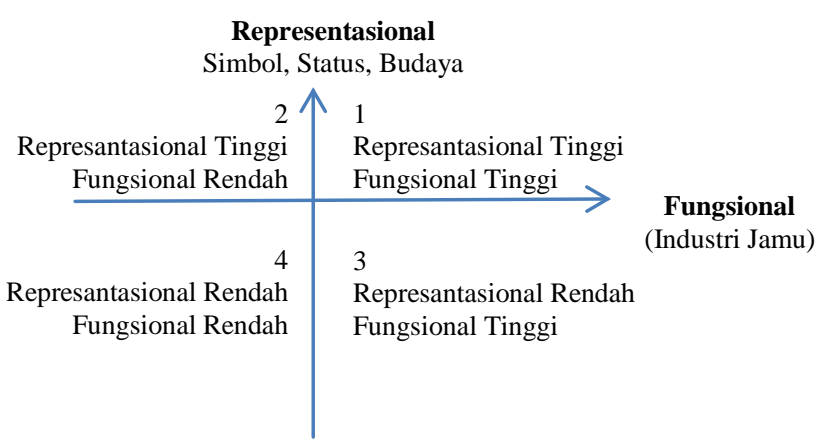

Gambar 1. Brand Box Model diadopsi dari Caldwell dan Freire (2004)

Nilai dari merek atau city branding di hasilkan dari kombinasi unsur representasional dan unsur fungsional. Pendekatan brand-box model merupakan salah satu pendekatan yang digunakan dalam menilai dan mengevaluasi model city branding dari sebuah kota. Nilai dari city branding yang di hasilkan akan menghasilkan berbagai outcome mulai dari minat untuk berinvestasi, minat untuk berkunjung dan minat untuk merekomendasikan.

\section{City Branding dan Simbolisme Produk}

Dalam konsep pemasaran, pengenalan produk melalui merek dapat dilakukan melalui dua pendekatan. Pendekatan pertama disebut dengan pendekatan fungsional yang menekankan citra merek berdasarkan fungsi dari produk tersebut, sedangkan pendekatan kedua berdasarkan pendekatan simbolik yang menekankan citra mereka melalui simbol simbol tertentu. Studi terkini menunjukkan justru unsur branding dengan model simbolik yang lebih bisa di terima oleh masyarakat dibanding dengan unsur fungsional. Aspek simbolik menjadi daya tarik yang lebih unggul di banding dengan pendekatan fungsional. Dari sisi konsumen, aspek simbolik justru lebih menarik. Tidak jarang produk tertentu justru menekankan unsur simboliknya yang akan meningkatkan status dari pengguna produk tersebut. Dengan mengarahkan produk jamu sebagai city branding dari daerah Sukoharjo melalui penekanan unsur simbolik dari produk 
tersebut akan mampu meningkatkan daya tarik city branding kota jamu di Sukoharjo.

Dari sisi pemasaran produk simbolik terkait dengan proses pengambilan keputusan konsumen yang di dekati dengan aspek irasional yang mengasumsikan konsumen merupakan individu yang memiliki unsur emosi sehingga dalam pengambilan keputusan seringkali mengedepankan aspek emosional.

Konsumsi simbolik mencerminkan kepribadian dan gaya hidup konsumen, mengekpresikan perbedaan sosial dan status sosial dari konsumen. Orang mengkonsumsi produk mewah untuk meningkatkan status mereka di masyarakat. Konsumsi berperan sebagai alat untuk mengekspresikan diri, dan proses ekspresi diri berhubungan dengan konsep diri dari individu. Pembelian produk memungkinkan konsumen untuk menjelaskan, memelihara dan meningkatkan konsep diri mereka. city branding identik dengan simbolisme produk. Orang berkunjung ke kota-kota tertentu selain untuk mendapatkan manfaat fungsional juga untuk mendapatkan manfaat simbol dan status mereka. Simbol dan status menjadi bagian yang penting dalam konsep city branding.

\section{City Branding dan Status}

Keinginan mendapatkan status menjadi salah satu motivator konsumen dalam berperilaku. Pembelian, penggunaan, penampilan, dan konsumsi barang dan jasa yang sering disebutkan ditujukan untuk mendapatkan status sosial. Peneliti seringkali menghubungkan antara keinginan untuk mendapatkan sosial status dengan tingkat perbedaan jenjang status yang di hasilkan dari tingkat pendapatan dan jenis jabatan yang di diskripsikan sebagai kelas sosial. Hubungan dengan jenjang sosial sangat penting untuk menjelaskan berbagai status sosial yang di miliki seseorang, perbandingan sosial individu dan kepemilikian simbol status yang memotivasi individu untuk mendapatkan status tersebut.

Vigneron dan Johnson (1999)

membagi konsep perilaku pencari status kedalam 5 (lima) dimensi meliputi conspicuousness, uniqueness, quality, extended self dan hedonism. Konsumen pencari status terbagi kedalam tiga segmen utama yaitu upmarket, premium dan luxury. Klasifikasi pencari status mengarahkan pada konsumen yang memiliki kemampuan keuangan untuk mendapatkan produk/jasa yang memiliki nilai status.

Status produk merupakan motivator yang kuat yang mendorong perilaku beli individu terhadap produk atau merek. Mason (1984) menemukan adanya pengaruh konsumsi status terhadap familiaritas merek, karakteristik dan rasa simbolik pada produk pakaian. Studi ekonomik meneliti status produk dari perspektif keseluruhan pasar, sementara pendekatan psikologi melihat status produk sebagai bentuk berbedaan variabel individu yang menjelaskan tentang variasi kepribadian konsumen. Konsumsi status di definisikan sebagai proses motivasi di mana individu berusaha meningkatkan kedudukan sosialnya melalui konsumsi berlebihan dari produk yang menyediakan simbol status bagi individu dan orang disekitarnya (Vigneron dan Johnson, 1999). Mason (1984) menyatakan bahwa konsumsi status merupakan proses mendapatkan status atau prestise sosial melalui kepemilikan dan konsumsi barang yang di persepsikan individu dan orang lain memiliki status tinggi.

Vigneron \& Johnson (1999) membedakan antara merek prestisius dan merek non prestisius. Adapun perbedaan kedua jenis merek tersebut diuraikan sebagai berikut :

1. Konsumsi merek mewah di pandang sebagai sinyal status dan kesejahteraan, harga merek tersebut lebih mahal di banding harga normalnya, mampu meningkatkan nilai yang melekat pada produk tersebut

2. Apabila semua orang memiliki merek tersebut, maka merek tersebut tidak lagi memiliki nilai lebih dibanding merek lain. Syarat prestise adalah di persepsikan memiliki nilai unik. 
3. Aspek peran dan nilai sosial dari merek prestise dapat di jabarkan dalam keputusan beli konsumen.

4. Untuk merek yang ditujukan untuk memuaskan hasrat emosional, manfaat intangible produk seperti tampilan estetika lebih mendominasi dalam pemilihan merek.

5. Prestise di turunkan dari keunggulan teknikal. Orang melihat prestise produk ketika produk tersebut memiliki kualitas yang superior di bandingkan dengan produk lain. Konsekuensi kualitas superior adalah harga yang lebih mahal di banding produk lain.

Vigneron dan Johnson (1999) membagi perilaku pencari status kedalam dua dimensi utama yaitu kesadaran diri dan pentingnya persepsi harga sebagai indikator dari status. Kesadaran diri mencerminkan respon konsumen terhadap pengaruh sosial, di definisikan sebagai kecenderungan yang konsisten dari individu untuk melakukan perhatian ke dalam dan keluar. Ada dua jenis kesadaran diri individu yaitu 1) kesadaran diri publik di mana individu lebih menekankan perhatian utama pada keberadaannya di depan orang lain dan 2) kesadaran diri privat di mana individu lebih memfokuskan pada perasaan dan pandangan dari dalam diri.

Konsumsi status merupakan pola konsumsi konsumen mengenai penampakan produk ke masyarakat. Produk mewah dan produk mode menjadi perhatian utama dari studi konsumsi status. Dari studi yang ada, barang tersebut memiliki hubungan hargakualitas yang raendah dan lebih banyak menampakkan pola harga-merek yang tinggi. Konsumsi status mencakup konsumsi produk kelas atas dan mewah yang jarang sekali di konsumsi konsumen secara normal. Konsumen tidak hanya menggunakan produk untuk memuaskan kebutuhan material nya namun juga untuk memuaskan kebutuhan sosialnya. Melalui konsumsi status, konsumen berusaha menunjukkan kepada orang lain tentang superioritas mereka di tempat kerja, koneksi sosial dan kemampuan keluarganya di masa depan. Dua teori psikologi yang digunakan untuk menjelaskan konsumsi status yaitu teori komparasi sosial dan teori identitas sosial (Lertwannawit dan Mandhachitara 2011).

Teori identitas sosial memfokuskan pada perilaku yang berhubungan dengan akuisisi konsumen terhadap kepemilikan atau penggunaan melalui aktivitas konsumsi dalam rangka untuk mengejar identitas yang berhubungan dengan tujuan akhir. Teori identitas sosial memandang konsumen secara realistis melalui berbagai bentuk keberadaan mereka dalam aktivitas sehari hari. Kekuatan eksternal dan kekuatan internal menjadi penggerak dari pengembangan identitas sosial. Teori identitas sosial berhubungan dengan kepemilikan menjelaskan kenapa konsumen memilih berbagai produk atau merek, konsumen mungkin menggunakan produk tersebut untuk mengekspresikan berbagai aspek dari identitas mereka, di pandu oleh stereotypes konsumsi dan harapan terhadap peran sosial. Ketidakpastian seringkali berkembang ketika perilaku yang berhubungan dengan identitas diri tidak konsisten dengan ekspektasi dari orang lain. Evaluasi diri di kembangkan untuk mengelola perilaku aktual dan memungkinkan peningkatan kesadaran akan perbedaan antara lingkungan sosial dan diri pribadi.

Teori komparasi sosial menyebutkan bahwa indivisu berusaha bersaing dan membandingkan dirinya dengan orang lain. Persaingan status lebih banyak terjadi pada bentuk akuisisi, kepemilikan dan konsumsi status atau produk mewah di bandingkan dengan reputasi pekerjaan, personal atau keluarga (Lertwannawit dan Mandhachitara, 2011). Individu berusaha membandingkan dan bersaing dengan orang lain dengan cara menunjukkan kekuatan sosial dan kekayaan mereka melalui kemampuan untuk membeli barang yang menunjukkan status sosial. Golongan menengah keatas mengkonsumsi secara berlebihan untuk menunjukkan posisi kelas sosial mereka yang tinggi dalam lingkungan sosialnya, sedangkan golongan menengah kebawah menggunakan konsumsi status untuk meningkatkan penghargaan diri. 
Konsumsi status di gunakan golongan menengah kebawah untuk menunjukkan keberadaan mereka.

Konsep city branding tidak lepas kaitannya dengan pengaruh informasional dalam bentuk pencitraan kepada masyarakat di luar kota tersebut. Pengaruh informasional di definisikan sebagai kecenderungan untuk menerima informasi dari orang lain sebagai fakta fakta realitas. Pengaruh informasional terjadi melalui dua cara, pertama individu mencari informasi tersebut melalui orang lain yang memiliki pengetahuan atau kedua, melalui inferensi berdasarkan obeservasi dari perilaku orang lain (Park dan Lessig, 1977). Pengaruh informasional terjadi melalui proses internasionalisasi di mana informasi yang berasal dari orang lain akan meningkatkan pengetahuan individu tentang beberapa aspek yang ada di lingkungan yang di hadapi. Pengaruh informasional memiliki dampak langsung terhadap proses pengambilan keputusan konsumen terkait dengan evaluasi produk.

\section{City Branding dan Budaya Lokal}

Orientasi budaya didefinisikan sebagai hasrat, keinginan, konsumsi, penampilan barang dan jasa yang diyakini konsumen secara umum yang bernilai karena alasan non utilitarian seperti status atau kesenangan. Keinginan memiliki barang material masih dalam benak konsumen, namun ada beberapa kondisi yang menyebabkan konsumen berusaha memenuhi keinginannya yaitu pertama, konsumen memiliki kemampuan keuangan untuk membeli barang tersebut. Kemampuan konsumen di negara maju jauh lebih baik di banding dengan negara berkembang atau negara terbelakang. Kondisi kedua, penyebaran budaya hedonisme menyebabkan konsumen menjadi lebih berorientasi pada nilai hedonis produk dibandingkan nilai utilitas dari produk. Kondisi ketiga, tingkat mobilitas produk yang menjadi semakin mudah di dapatkan konsumen karena adanya perdagangan bebas sehingga menyebabkan konsumen mudah terpengaruh untuk mendapatkan barang tersebut.
Orientasi nilai modern merupakan bagian dari budaya konsumen. Salah satu alasan kenapa orang menggunakan produk yang bermerek meskipun memiliki harga yang jauh lebih tinggi di banding dengan manfaat produk adalah karena orang ingin mendapatkan status sosial. Status sosial yang di tunjukkan dengan penggunaan produk menjadi bagian dari cara individu menyampaikan aktualisasi dirinya. Pembelian produk karena status sosial menunjukkan konsumen tidak lagi rasional dalam membeli produk, faktor yang di pertimbangkan bukan manfaat fungsional produk akan tetapi lebih pada manfaat simbolik dari produk. Ketika budaya konsumen sudah mengarah pada orientasi simbolik, maka pola konsumsi yang diutamakan adalah pola konsumsi simbolik. budaya akan mempengaruhi cara pemikiran konsumen sebagai bagian dari budaya tersebut. Orientasi simbolik di yakini melekat pada produk tertentu dan akan menunjukkan gengsi pemakai produk. Contoh fenomena budaya simbolik yang ada di Indonesia terjadi pada konsumsi produk telepon genggam atau handphone. Pembelian produk handphone menjadi sarana konsumen untuk menunjukkan gengsi mereka. Konsumen meyakini produk tersebut memberikan status bagi mereka sehingga dampat lebih jauh yang bisa di lihat meskipun konsumen tidak butuh handphone, namun mereka tetap membeli. Tidak memiliki handphone di pandang sebagai orang ketinggalan jaman. Proses penanaman nilai nilai simbolik pada produk handphone berdampak luar biasa, tidak hanya pada kelas masyarakat yang mampu namun juga pada kelas masyarakat miskin. Dampak lebih jauh yang dirasakan adalah konsumsi penggunaan handphone menjadi meningkat untuk tujuan simbolisme bukan untuk produktivitas.

Yoo dan Han (2006) menunjukkan adanya pengaruh merek ekslusif terhadap sinyal kesejahteraan dan sinyal status. Merek menjadi pertanda status seseorang. Merek berperan dalam membentuk persepsi seseorang melalui manfaat simbolik yang di lekatkan pada merek tersebut. Fenomena 
konsumsi simbolik pada masyarakat menengah ke bawah perlu di perhatikan secara serius. Ketika orientasi budaya masyarakat menengah ke bawah lebih berorientasi pada simbolik maka tingkat pengeluaran yang mereka lakukan akan semakin tinggi. Hal ini berakibat pada skala prioritas konsumsi yang akan bergeser. Pada konteks city branding, persepsi eksklufivitas dari produk jamu harus di gali terlebih dahulu.

\section{Deutch dan Gerrard (1955)} menemukan adanya pengaruh orientasi nilai budaya terhadap konsumsi barang mewah. Hasil penelitiannya menunjukkan kecenderungan orang mengkonsumsi barang mewah lebih di dominasi oleh budaya/nilai nilai yang diyakini dibanding dengan tingkat pendapatan yang mereka miliki. Barang mewah di konsumsi karena mengandung nilai-nilai simbolik pada individu. Manfaat simbolik menjadi faktor penting yang menarik orang untuk mengkonsumsi produk atau jasa. Kecenderungan konsumsi simbolik yang di pengaruhi oleh faktor budaya menunjukkan adanya pergeseran orientasi nilai nilai yang diyakini oleh masyarakat tradisional ke nilai-nilai modern yang ditunjukkan oleh simbolisme produk/jasa.

\section{Pariwisata Industri}

Pariwisata industri menyediakan tempat bagi pengunjung untuk merasakan budaya merek, mendapatkan pengetahuan tentang produk, bersenang senang, belajar tentang proses pembuatan produk dan berpartisipasi pada berbagai kegiatan langsung terkait dengan produk (Chow et al, 2017). Pariwisata industri telah berkembang pesat dalam dua dekade terakhir, mencakup industri yang menjual berbagai produk termasuk makanan dan minuman, peralatan, mobil, mainan, tembikar, barang olah raga dan lain-lain. Sejumlah pariwisata industri yang berkembang pesat ada di sektor makanan dan minuman. Pariwisata industri memberikan keuntungan bagi perusahaan yang terlibat di dalamnya seperti mengamankan reputasi perusahaan, membangun hubungan dengan masyarakat, meningkatkan citra merek, menciptakan ikatan antar konsumen, merek dan perusahaan, meningkatkan loyalitas merek. Manfaat langsung yang di dapatkan adalah meningkatkan penjualan (Otgaar, 2012). Konsep kota jamu yang dipakai oleh Kota Sukoharjo masuk kedalam konsep pariwisata industri. Menggunakan industri jamu sebagai elemen utama untuk menarik pengunjung wisatawan ke Sukoharjo.

\section{City Branding}

City branding merupakan praktek umum yang diadopsi oleh banyak kota untuk menarik wisatawan dan investasi ke dalam sekaligus mempromosikan pembangunan yang di lakukan. Sebuah kota perlu mengadopsi strategi yang tepat agar memiliki identitas tersendiri. City branding tergantung pada identifikasi ciri khas dan karakteristik yaang dimiliki oleh kota tersebut. Strategi city branding sering menekankan pada budaya dan kreativitas untuk menciptakan identitas yang khas yang menangkap keunikan kota sekaligus mempromosikan citra kota yang menarik (Liu, 2016).

Branding mengacu pada semua proses dan aktivitas yang terlibat dalam menciptakan merek. Branding dipahami sebagai model komunikasi yang brtujuan untuk memposisikan produk atau layanan yang berbeda dengan pesaingnya. Kebutuhan untuk merek kota di tetapkan sebagai salah satu alat pemasaran penting yang di perlukan untuk memastikan kota wisata yang kompetitif. Merek tidak hanya sekedar logo, tetapi merangkum bagaimana pengalaman pengunjung yang luar biasa dan memberi kesan yang mendalam (Smith, 2006). Tujuan dari branding untuk mengenalkan nilai fungsional dan simbolik, dan merubah perilaku konsumen dengan meningkatkan ketertarikan dan loyalitas pada merek. City branding yang kuat diyakini merupakan kunci sukses dalam pengembangan kota, menyediakan pengerak yang kuat untuk berkunjung ke kota dan mencapai keuntungan maksimum dari stakeholder. Untuk menciptakan merek yang kuat, kota 
membutuhkan produk dan layanan yang berdampak pada persepsi kualitas dan nilai yang meningkatkan marketshare dan loyalitas konsumen (Cox dan Wray, 2011).

\section{Outcome City Branding}

Han et al (2010) menemukan adanya hubungan yang kuat antara evaluasi yang positif terhadap produk dengan keinginan untuk mengunjungi hotel. Niat untuk berkunjung merupakan outcome dari persepsi penilaian terhadap layanan hotel. Studi pada hotel ramah lingkungan menunjukkan adanya hubungan yang kuat antara persepsi value dengan niat untuk berkunjung ke hotel (Chen dan Tung, 2014). Hultman, Kazeminia dan Ghazemi (2015) dalam studi yang di lakukan pada wisatawan di Swedia dan Taiwan menemukan adanya pengaruh yang kuat antara sikap terhadap ecotourism terhadap keinginan untuk berkunjung. Lee, Huh dan Hong (2008) dalam studi yang dilakukan pada pengunjung festival Contore Cajun Catfish di Texas menemukan adanya hubungan yang kuat antara pesepsi nilai layanan dengan keinginan untuk berkunjung ke festival tersebut. Brida et al 2012 dalam studinya menemukan selain minat berkunjung, outcome dari persepsi destinasi adalah minat untuk merekomendasikan pada orang lain. Persepsi terhadap nilai city branding berpengaruh terhadap minat untuk berkunjung dan minat untuk merekomendasikan.

\section{METODE}

Studi ini dilakukan untuk meneliti pengaruh persepsi citra kota terhadap minat untuk berkunjung dan minat untuk merekomendasikan. Model yang dipakai dalam penelitian ini dapat dilihat pada gambar 2 berikut:

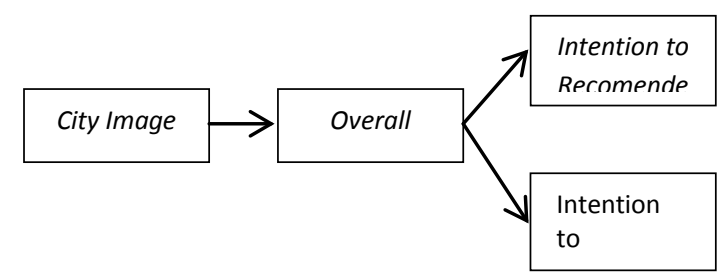

Gambar 2. Model Perspesi City Image

\section{Disain Penelitian}

Penelitian ini termasuk dalam kategori penelitian kausal, di mana penelitian bertujuan untuk menjelaskan hubungan antar variabel, variabel yang satu menyebabkan atau menentukan nilai variabel yang lain (Aaker, Kumar, dan Day, 2001; Cooper dan Schindler, 2001). Sementara metode pengumpulan data yang digunakan adalah studi komunikasi atau interogasi, artinya data di peroleh melalui hasil tanggapan atau jawaban responden atas daftar pertanyaan (instrumen) yang di berikan peneliti di lokasi penelitian yang telah di tentukan. Dari sisi dimensi waktu, penelitian ini termasuk dalam kategori penelitian cross-sectional, yaitu penelitian yang hanya mengambil data melalui penyebaran kuesioner hanya dalam satu saat saja. (Cooper dan Schindler, 2001).

\section{Target Responden}

Unit analisis yang di teliti berupa individu. Sementara itu, jumlah populasi penelitian dan sampling frame tidak di ketahui oleh peneliti, sehingga sampel di ambil dengan metoda non probabilitas, artinya setiap elemen di dalam populasi tidak memiliki probabilitas yang sama untuk dipilih menjadi sampel atau pemilihan anggota sampel ditentukan dengan tidak acak.

\begin{tabular}{lcr}
\multicolumn{1}{c}{ Beberapa } & pertimbangan & peneliti \\
menggunakan & pengambilan & sampel \\
nonprobabilitas & adalah, & prosedur
\end{tabular}
pengambilan sampel ini memenuhi tujuan pengambilan sampel secara memuaskan. Selain itu, pertimbangan waktu, biaya, dan tenaga. Pertimbangan ketiga, pengambilan sampel nonprobabilitas merupakan satusatunya alternatif yang cocok (feasible) apabila populasi total tidak tersedia atau tidak di ketahui peneliti (Cooper dan Schindler, 2001).

Ada beberapa alasan mengapa peneliti menggunakan sebagian elemen populasi (sampel) untuk di teliti. Pertama, dalam praktek peneliti tidak mungkin melakukan pengumpulan dan pengujian terhadap setiap elemen populasi. Kedua, pengumpulan dan pengujian terhadap setiap 
elemen populasi (jika memungkinkan), akan memerlukan banyak waktu, biaya, dan orang yang melaksanakan. Ketiga, penelitian terhadap sebagian elemen populasi, kadangkadang memberikan hasil yang lebih dapat di percaya dan kesalahan dalam pengumpulan data relatif lebih kecil, terutama jika elemenelemen terdiri atas banyak data. Keempat, pengujian terhadap seluruh elemen populasi, dalam kasus tertentu tidak mungkin di lakukan (Sekaran, 2000; Cooper dan Schindler, 2001).

Jumlah sampel yang diperlukan untuk pengujian model dengan menggunakan SEM (stuctural equation modelling) adalah berkisar antara 100-200 untuk tiap kategori produk atau ukuran sampel minimum adalah 5 observasi untuk setiap estimeted parameter (Hair et. al 2010). Karena ada 11 item pertanyaan maka sampel yang optimal di atas 110 responden. Untuk memenuhi ukuran sampel minimum maka jumlah sampel yang akan di ambil adalah tiap daerah sebanyak 250 responden. Daerah yang menjadi target penelitian adalah daerah di luar Kota Sukoharjo meliputi Solo, Karanganyar, Sragen, dan Boyolali.

Branding destinasi wisata jamu bertujuan untuk menarik masyarakat diluar Kota Sukoharjo agar berkunjung ke Sukoharjo untuk menikmati wisata jamu. City branding yang dilakukan ditujukan terhadap masyarakat diluar Kota Sukoharjo. Branding yang di lakukan di tujukan untuk masyarakat luar, bukan masyarakat Sukoharjo. Sampel penelitian ini adalah responden yang berdomisili di luar Kota Sukoharjo. Total sampel sebesar 1000 responden (4 daerah x 250 responden) Teknik pengambilan sampel yang digunakan adalah convenience sampling.

Struktur pertanyaan dalam kuesioner berupa pertanyaan tertutup. Responden akan di minta mengisi sendiri jawaban yang tersedia, namun demikian peneliti akan tetap mendampingi responden untuk memudahkan responden dalam menjawab pertanyaan. Kuesioner ini di gunakan untuk mendapatkan data primer, sedangkan data sekunder di kumpulkan melalui studi pustaka dari buku, dan jurnal pemasaran untuk menyusun tinjauan pustaka dan penggunaan alat analisis. Instrumen penelitian yang di gunakan mengadopsi dari Hosany, Ekonci dan Uysal (2006) dan Lee dan Xie (2009)

\section{Prosedur Analisis}

Pengujian model yang di hipotesiskan dalam penelitian ini menggunakan teknik structural equation modelling. SEM merupakan teknik multivariat yang mengkombinasikan aspek regresi berganda dan analisis faktor untuk mengestimasi sekumpulan hubungan ketergantungan yang saling berkaitan secara simultan. Pengujian SEM terutama berguna ketika satu variabel dependen menjadi variabel independen pada hubungan dependensi berikutnya. Pengujian menggunakan SEM, pertama-tama peneliti mempelajari teori, pengalaman sebelumnya, dan tujuan penelitian untuk membedakan variabel independen mana yang memprediksikan variabel dependen tertentu. Hubungan yang diusulkan kemudian di translasikan menjadi suatu kumpulan persamaan struktural untuk masing-masing variabel dependen. Persamaan-persamaan tersebut kemudian diuji secara simultan (Hair et. al., 2010). Pada program statistik AMOS 20 hubungan-hubungan tersebut tidak perlu di tuliskan dalam bentuk persamaan, namun dapat di ganti oleh gambar model yang melukiskan hubungan kausalitas antar variabel yang diteliti. Pada penelitian ini, pendekatan SEM satu tahap (one steps approach to SEM) di gunakan untuk menguji model struktural yang di ajukan. Adapun langkah dalam analisis SEM sebagai berikut:

1. Pengujian Validitas dan Reliabilitas.

Validitas suatu alat ukur mengacu pada apakah suatu alat ukur dapat mengukur apa yang sebenarnya ingin diukur. (Cooper dan Schindler, 2001). Dalam hal ini pengujian validitas dilakukan terhadap uji construct validity, yang menunjukkan seberapa baik hasil yang di peroleh dari penggunaan alat ukur sesuai dengan teori 
di mana pengujian di rancang (Sekaran, 1992).

Reliabilitas merupakan pengujian tingkat konsistensi antara berbagai butir pengukuran pada suatu variabel (Hair et. al., 2010). Untuk mengestimasi reliabilitas setiap variabel di gunakan koefisien cronbach's alpha. Selain itu, item to total correlation di gunakan untuk memperbaiki pengukuran dengan mengeliminasi butir-butir yang kehadirannya akan memperkecil cronbach's alpha yang dihasilkan. Rules of tumb yang dipakai adalah item-total correlation masing-masing butir harus lebih besar dari 0,50 dan cronbach's alpha harus lebih besar dari 0,70, meskipun Sekaran (2000) mengemukakan bahwa nilai item-total-correlation lebih kecil dari 0.50 tetap dapat diterima jika item-item yang di eliminasi akan menghasikan koefisien cronbach's alpha yang lebih kecil

2. Pengujian Asumsi Model Struktural

Dalam Hair et.al. (2010) di sebutkan SEM terutama bila di estimasi dengan maximum likelihood estimation technique mensyaratkan sebaiknya asumsi normalitas pada data di penuhi. Nilai statistik untuk menguji normalitas disebut z value (Critical Ratio atau C.R pada output AMOS 20) dari ukuran skewness dan kurtosis sebaran data. Bila nilai C.R lebih besar dari nilai kritis maka dapat di duga bahwa distribusi data tidak normal. Nilai kritis dapat ditentukan berdasarkan tingkat signifikansi $1 \%$ yaitu sebesar > 2.58 .

Outlier adalah data yang memiliki karakteristik unik yang terlihat sangat berbeda jauh dari observasi-observasi lainnya dan muncul dalam bentuk nilai ekstrim baik untuk variabel tunggal maupun variabel kombinasi. Dalam analisis multivariate adanya outlier dapat di uji dengan statistik chi square (x2) terhadap nilai mahalanobis distance squared pada tingkat signifikansi 0.001 dengan degree of freedom sejumlah konstruk yang digunakan dalam penelitian (Hair et al., 2010).

3. Pengujian Goodness of Fit Indeks Pengujian goodness of fit indeks dilakukan dengan menggunakan beberapa kriteria meliputi X2, RMSEA, GFI, AGFI, CMIN/DF, TLI, CFI, NFI (Hair et al 2010).

4. Pengujian Model Struktural

Setelah model di nyatakan fit, atau di terima secara statistik maka langkah selanjutnya adalah melakukan pengujian hipotesis dengan bantuan AMOS 20 dengan menganalisis hubungan diantara variabel-variabel laten. SEM juga dapat mengestimasi nilai-nilai path dari setiap hubungan variabel. Dengan menggunakan analisis SEM maka semua hipotesis dalam studi ini dapat di uji dengan melihat nilai probability yang di tunjukkan oleh output AMOS 20. Dalam penelitian ini, pengujian hubungan kausalitas antar variabel dialkukan dengan uji satu sisi pada tingkat signifikansi sebesar $1 \%, 5 \%$, dan 10\%. Hal ini di dasarkan pada pernyataan Hair, et. al,. (2010) yang menyebutkan bahwa penentuan nilai kritis tergantung pada penentuan teoritis mengenai hubungan yang di prediksi.

\section{HASIL DAN PEMBAHASAN}

Survey dilakukan untuk menilai persepsi masyarakat terhadap city image dari Kota Sukoharjo di bandingkan dengan kota lain. Sebagai pembanding digunakan kota Yogyakarta. Survey di lakukan untuk menguji hubungan antara city image dengan minat untuk berkunjung dan minat untuk merekomendasikan. Survey di lakukan pada masyarakat di luar Kota Sukoharjo. City image dari Kota Sukoharjo di nilai berdasarkan persepsi dari masyarakat di luar Kabupaten Sukoharjo. Penyebaran kuesioner dilakukan di kota di luar Kabupaten Sukoharjo meliputi Solo, Boyolali, Sragen dan Karanganyar. Dari total 1000 kuesioner yang disebar, terdapat 134 kuesioner yang tidak valid (jawaban tidak lengkap, pengisian asal) dan 866 kuesioner dinyatakan valid. Prosentase 
respon rate pengisian kuesioner rata-rata sebesar $87 \%$, dengan tingkat respon rate tertinggi ada pada daerah Boyolali sebesar 98\% dan tingkat respon rate terendah ada pada daerah Sragen dengan prosentase sebesar $81 \%$.

\section{Pengujian Validitas dan Reliabilitas}

Pengujian validitas di lakukan melalui Corfirmatory Factor Analysis (CFA). CFA perlu di lakukan terhadap model pengukuran, karena syarat untuk dapat menganalisis model dengan SEM, indikator masing-masing konstruk harus memiliki yang signifikan terhadap konstruk yang di ukur. Indikator masing-masing konstruk yang memiliki loading factor yang signifikan membuktikan bahwa indikator tersebut merupakan satu kesatuan alat ukur yang mengukur konstruk yang sama dan dapat memprediksi dengan baik konstruk yang seharusnya di prediksi (Hair et al, 2010). Uji Validitas dilakukan dengan menggunakan confirmatory factor analysis melalui sofware SPSS. Berdasarkan hasil perhitungan confirmatory factor analysis yang di sajikan pada menunjukkan convergent validity yang bisa di terima karena semua item mempunyai factor loading yang lebih dari 0,40 dan signifikan pada taraf signifikansi $5 \%$. Dari hasil faktor analisis ada beberapa item pertanyaan yang harus di keluarkan karena tidak memenuhi persayaratan validitas item pertanyaan ini harus di hilangkan.

Hasil pengujian faktor analisis menunjukkan semua indikator terekstrak sesuai dengan klasifikasinya. Tidak terdapat indikator yang muncul di dua tempat. Dapat di simpulkan data yang di pakai lolos dari uji validitas dan memiliki tingkat validitas yang tinggi. Setelah di lakukan uji validitas selanjutnya di lakukan uji reliabilitas. Pengujian reliabilitas setiap konstruk dilakukan dengan menggunakan koefisien Cronbach's Alpha. Dari hasil uji reliabilitas di dapatkan nilai croncbach alpha pada semua konstruk lebih besar dari 0,6.
Tabel 1. Hasil Uji Reliabilitas

\begin{tabular}{lcc}
\hline Variabel & $\begin{array}{c}\text { Nilai } \\
\text { Alpha }\end{array}$ & Keterangan \\
\hline City Image & 0,873 & Diterima \\
Overall Value & 0,870 & Diterima \\
Rekomendasi & 0,913 & Diterima \\
Berkunjung & 0,928 & Diterima \\
\hline
\end{tabular}

Sumber: data diolah

\section{Pengujian Model Struktural}

Hubungan hipotesis konstrukkonstruk penelitian pada model yang di ajukan di tunjukkan hubungan kausal antar konstruk tersebut.

Nilai X2 - chi square sebesar 209,717 dengan tingkat signifikansi 0.000 Berdasarkan analisis terhadap goodness of fit secara umum menunjukkan bahwa model pengukuran yang di gunakan dapat di terima.

The Minimum Sample Discrepancy Function - CMN/DF merupakan indeks kesesuaian parsimonious yang mengukur hubungan goodness of fit model dan jumlah koefisien-koefisien estimasi yang di harapkan untuk mencapai tingkat kesesuaian. Dengan nilai yang di rekomendasikan CMIN/DF $\leq 3.0$, menunjukkan model fit yang sangat baik.

Goodness of fit index - GFI mencerminkan tingkat kesesuaian model secara keseluruhan. Dengan tingkat penerimaan yang direkomendasikan GFI > 0.90, disimpulkan bahwa model memiliki GFI 0,958 diatas 0,9 sehingga dapat di katakan memiliki tingkat kesesuaian model yang baik.

Adjusted goodness of fit index AGFI sebagai pengembangan indeks dari GFI, merupakan indeks yang telah di sesuaikan dengan rasio degree of freedom model yang diusulkan dengan degree of freedom dari null model. Dengan nilai penerimaan yang direkomendasikan AGFI > 0.90, di simpulkan bahwa model memiliki AGFI 0,923 sehingga dapat di katakan memiliki tingkat kesesuaian yang baik.

Comparative Fit Index - CFI, indeks kesesuaian incremental yang membandingkan model yang di uji dengan null model. Dengan memperhatikan nilai 
yang di rekomendasikan CFI $>0.90$, nilai 0,976 menunjukkan model memiliki kesesuaian yang baik.

The Root Mean Square Error of Approximation - RMSEA, indeks yang digunakan untuk mengkompensasi chisquare statistic dalam sampel yang besar. Nilai RMSEA menunjukkan yang dapat di harapkan bila model diestimasi dalam populasi. Nilai penerimaan yang direkomendasi RMSEA $<0.08$, nilai 0,075 menunjukkan nilai kesesuaian yang baik. Nilai RMR yang di syaratkan adalah sebesar $<0.03$, nilai 0,027 menunjukkan nilai kesesuaian yang baik.

Tucker Lewis Index - TLI merupakan alternatif incremental fit index yang membandingkan model yang diuji dengan baseline. Nilai yang di rekomendasikan sebagai tingkat kesesuaian yang baik TLI > 0.90, nilai 0,964 menunjukkan kesesuaian model yang baik.

Normed Fit Index - NFI, membandingkan model yang diuji dengan baseline model. Dengan nilai penerimaan yang direkomendasikan NFI $>0.90$, nilai 0,971 menunjukkan model ini memiliki nilai fit yang baik.

Secara keseluruhan dapat disimpulkan bahwa syarat nilai goodness of fit model struktural telah terpenuhi. Setelah kriteria goodness of fit dapat terpenuhi atas model struktural yang di estimasi, selanjutnya analisis terhadap hubunganhubungan struktur model (pengujian hipotesis) dapat di lakukan. Hubungan antar konstruk dalam hipotesis di tunjukkan oleh nilai standardized regression weights.

Pengujian hipotesis di lakukan pertama, dengan menganalisa tingkat signifikansi hubungan kausalitas antar konstruk dalam model yang didasarkan pada nilai C.R. Kedua, dengan melihat standardized structural (path) coefficients dari setiap hipotesis terutama pada kesesuaian arah hubungan path dengan arah hubungan yang telah di hipotesiskan sebelumnya. Jika arah hubungan sesuai dengan yang di hipotesiskan dan nilai critical ratio-nya juga memenuhi persyaratan maka dapat di katakan bahwa hipotesis yang diuji mendapat dukungan yang kuat. Nilai kritis yang digunakan adalah nilai z-tabel dengan degree of freedom 242 yaitu sebesar $1,96(\alpha=0,05$, two tailed $)$.

\section{Pengujian Hubungan Antara City Image dengan Overall Value}

Berdasarkan hasil analisa model struktural yang menguji hubungan pengaruh antara City Image dengan Overall Value didapatkan hasil nilai CR sebesar 16,912 dengan nilai SE sebesar 0,000. Nilai CR > dari \pm 1,96 maka menunjukkan adanya pengaruh yang kuat antara persepsi terhadap city image dan overall value. Hal ini dapat di simpulkan bahwa sebagaian besar responden menilai kota tujuan berdasarkan persepsi mereka yang terbentuk oleh adanya informasi yang masuk pada diri mereka. Pengaruh yang kuat ini menunjukkan orang menilai kota tujuan berdasarkan persepsi mereka.

Pengaruh City image terhadap city value yang kuat menunjukkan dalam konteks brand-box model, city branding yang dilakukan oleh Kabupaten Sukoharjo masuk ke dalam unsur fungsional yang tinggi dan representasional yang tinggi atau di kuadran 1. Caldwell dan Freire (2004) menyebutkan pada kuadran 1, city branding yang di bangun sejalan dengan keinginan masyarakat. Masyarakat menilai apa yang diharapkan dengan yang dirasakan sama. Brida et al (2012) menyebutkan pada konteks wisatawan, kondisi tersebut akan mengarahkan pada loyal terhadap tujuan wisata.

\section{Pengujian Hubungan Antara Overall Value dengan Intention to Recomend}

Berdasarkan hasil analisa model struktural yang menguji hubungan pengaruh antara Overall Value dengan Intention to Recomended di dapatkan hasil nilai CR sebesar 16,943 dengan nilai SE sebesar 0,000. Nilai CR $>$ dari $\pm 1,96$ maka menunjukkan adanya pengaruh yang kuat antara Overall Value terhadap Intention to Recomended. Hal ini dapat di simpulkan 
bahwa sebagian besar responden akan merekomendasikan kota tujuan yang dianggap bernilai bagus pada orang lain. Nilai CR sebesar 16,943 menunjukkan adanya pengaruh yang sangat kuat. Brida et al (2012) menyebutkan intention to recommend dipengaruhi oleh persepsi terhadap human capital dan physical capital dari destinasi wisata yang ada. Intention to recommen merupakan bentuk dari persepsi positif terhadap destinasi wisata. Value positif yang di hasilkan dari city branding akan berdampak pada minat untuk merekomendasikan tujuan tersebut kepada orang lain.

\section{Pengujian Hubungan Antara Overall Value dengan Minat untuk berkunjung} Berdasarkan hasil analisa model struktural yang menguji hubungan pengaruh antara Overall Value dengan Intention to Visit di dapatkan hasil nilai CR sebesar 17,355 dengan nilai SE sebesar 0,000. Nilai $\mathrm{CR}>$ dari $\pm 1,96$ maka menunjukkan adanya pengaruh yang kuat antara Overall Value terhadap Intention to Visit. Hal ini dapat di simpulkan bahwa sebagian besar responden memiliki minat yang besar untuk berkunjung ke kota tujuan yang dianggap bernilai bagus. Nilai CR sebesar 17,355 menunjukkan adanya pengaruh yang sangat kuat.

Zeithaml (1988) mendefinisikan konsep value ke dalam 4 definisi utama meliputi value karena berharga murah, value karena di inginkan konsumen, value karena kualitas produk, dan value karena kesesuaian apa yang di dapatkan dengan apa yang di tawarkan. Value city branding terbentuk karena apa yang di dapatkan sesuai dengan apa yang di harapkan.

Hasil riset ini sejalan dengan hasil penelitian dari Bajs (2013) yang menemukan adanya hubungan yang kuat antara perceived value terhadap behavioral intention. Value yang kuat dari city branding yang di canangkan akan berdampak pada minat masyarakat untuk berkunjung ke Sukoharjo.

\section{Kesimpulan}

Penelitian ini menitikberatkan pada bagaimana membangun city branding melalui penguatan persepsi orang terhadap kota tertentu. Studi ini menunjukkan adanya pengaruh yang kuat antara persepsi image dari kota dengan overall value, dan pengaruh yang kuat antara overall value terhadap intention to recommend dan intention to visit. Hal ini menunjukkan minat responden untuk berkunjung ke kota tertentu di pengaruhi oleh persepsi positif yang terbentuk terhadap kota tertentu. Semakin kuat persepsi positif yang terbentuk maka semakin kuat keinginan untuk berkunjung ke kota tertentu. Persepsi positif yang kuat tidak hanya berpengaruh terhadap minat untuk berkunjung, tetapi juga berpengaruh kuat terhadap minat untuk merekomendasikan. Orang akan berkunjung ke kota tertentu berdasarkan persepsi mereka dan rekomendasi terhadap kota tersebut. Persepsi di bentuk melalui berbagai cara, persepsi kota wisata dapat dibentuk secara viral melalui pengenalan terhadap keunggulan kota tersebut. Keunggulan kota yang di kenalkan secara online akan mendorong orang untuk berkunjung terhadap kota tersebut.

\section{DAFTAR PUSTAKA}

Kumar, V., David A. Aaker, and George S. Day. 2001. Essentials of marketing research. New York: Wiley.

Bajs, P. Irena , 2013, Tourist Perceived Value, Relationship to Satisfaction, and Behavioral Intentions, Journal of Travel Research, 54(1),122-134.

Brida, Juan Gabriel; Pulina, Manuela; Riao, Eugenia; Zapata-Aguirre, Sandra , 2012, Cruise visitors intention to return as land tourists and to recommend a visited destination, Anatolia An International Journal of Tourism and Hospitality Research, 23-3, 395-412.

Bergman, Amanda (2010), "Conspicuous Consumption: A Studi of Pretige Related Consumer Behavior."

Caldwell, N., Joao R. Freire (2004), The differences between branding a country, a region and a city: Applying 
the Brand Box Model. Brand Management, 12(1), 50-61

Campbell, Colin (2011), “Conspicuous Confusion? A Critique of Veblen's Theory of Conspicuous Consumption," Sociological Theory.

Chen, M., dan Pei-Ju Tung, (2014), "Developing and Extended Theory of Planned Behavior model to predict consumer' intention to visit green hotel," International Journal of Hospitality Management. 36(2014), 221-230.

Chow, Hsueh-wen; Ling, Guo-Jie; Yen, Iyin; Hwang, Kuo-Ping , 2017, Building brand equity through industrial tourism, Asia Pacific Management Review, 22-2

Cooper, D.R. and Schindler, P.S. (2001) Business Research Methods. McGrawHill Higher Education, London.

Cox, C. dan Wray, M. (2011), "Best practice marketing for regional tourism citys", Journal of Travel \& Tourism Marketing, Vol. 28 No. 5, 524-540.

Deutsch, Morton dan Harold B Gerrard (1955) “A Study of Normative and Informational Social Influences Upon Individual Judgment. The Journal of Abnormal and Social Psycholog. 51(3): 629-636

Dinnie, Keith. 2011.City Branding: Theory and Cases. London: Palgrave Macmillan, London.

Hair Jr., J.F., Black, W.C., Babin, B.J. and Anderson, R.E. (2010) Multivariate Data Analysis: A Global Perspective. 7th Edition, Pearson Education, Upper Saddle River.

Han, H., Hsu, L.-T., Sheu, C., 2010. Application of the theory of planned behavior to green hotel choice: testing the effect of environmental friendly activities. Tourism Management, 31 (3), 325-334.

Hosany, Sameer, dan Drew Martin (2012), "Self-image congruence in consumer behavior," Journal of Business Research, 65(5), 685-91.

Hosany, S., Y. Ekinci, and M. Uysal. (2006).
"Destination Image and Destination Personality: An Application of Branding Theo-ries to Tourism Places.” Journal of Business Research, 59 (5): 638-42

Hsuesh W.C., Jing, G., Yen, I., dan KuoPing Hwang (2017) Building Brand Equity Through Industrial Tourism. Asia Pacific Management Review. 22, 70-79

Hultman, M., Kazeminia, A., Vahid Ghasemi, (2015). "Intention to visit and willingness to pay premium for ecotourism: The impact of attitude, materialism, and motivation," Journal of Business Research. 68-9, 18541861.

Kim, Seongseop (Sam); Choe, Ja Young (Jacey); Petrick, James F. , 2018, The effect of celebrity on brand awareness, perceived quality, brand image, brand loyalty, and destination attachment to a literary festival , Journal of Destination Marketing \& Management, 9(2018), 320-329.

Lertwannawit, A., dan Mandhachitara, R. (2011), “Interpersonal Effects on Fashion Consciousness and Status Consumption Moderated by Materialism in Metropolitan Men.” Journal of Business Research.

Lee, J., Xie, K.L. (2009). Cognitive Destination Image, Destination Personality and Behavioral Intention: An Integrated Perspective of Destination Branding. Research Article The Hongkong Polytechnic University and Temple University. Available at http://scholarworks.umass.edu/gradcon f_hospitality/2011/Presentation

Liu, Yi-De (2016) Major Event and City Branding: An Evaluation of Liverpool as the 2008 European Capital of Culture. Journal of Place Management and Development. 8(2), 147-162.

Mason, R. (1984), "Conspicuous consumption: A literature review," European Journal of Marketing, 18(3), 26-39. 
Myfanwy Trueman, Nelarine Cornelius, James Wallace, (2012) "Building brand value online: exploring relationships between company and city brands", European Journal of Marketing, Vol. 46 Issue: 7/8, 1013-1031

Ng, Siew Imm; Lee, Julie Anne; Soutar, Geoffrey N. , 2007, Tourists intention to visit a country: The impact of cultural distance , Tourism Management, 28-6, 1497-1506

Nicosia, Francesco M (1966), Consumer decision processes; marketing and advertising implications, Englewood Cliffs, N.J.: Prentice-Hall.

Otgaar, A. (2012). Towards a common agenda for the development of industrial tourism. Tourism Management Perspectives, 4,

Park, C.W. and Lessig, V.P. (1977) Students and Housewives: Difference in Susceptibility to Reference Group Influence. Journal of Consumer Research, 3, 102-110.

Sekaran, U. (2000) Research Methods for Business: A Skill Business Approach. John Wiley \& Sons, New York.

Shukla, Paula (2010), "Status Consumption in Cross National Context. Socio Psychological, brand and situational antecedents,” International Marketing Review, 27(1), 108-129.

Shukla, Paurav, dan Keyoor Purani (2011), "Comparing the importance of luxury value perceptions in cross-national contexts," Journal of Business Research.

Smith, A. (2006), “Assessing the contribution of flagship projects to city image change: aquasi-experimental technique", International Journal of Tourism Research, Vol. 8 No. 6, 391-404.

So-Yon Lee, Jin Huh \& Sung-Kwon Hong (2008) Determining Behavioral Intention to Visit a Festival Among First-Time and Repeat Visitors, International Journal of Tourism Sciences, 8:1, 39-55
Veblen, Thorstein (1899), The Theory of the Leisure Class.

Vigneron, F., dan L. W. Johnson (1999), “A review and a conceptual framework of prestige-seeking consumer behavior," Academy of Marketing Science Review, 1(1), 1-15.

Yoo, Boonghee, dan Seung-Hee Lee (2011), "Asymmetrical effects of past experiences with genuine fashion luxury brands and their counterfeits on purchase intention of each," Journal of Business Research.

Yoo, Shijin, Seh-Woong Chung, dan Jin K. Han (2006), “A Durable Replacement Model for Symbolic versus Utilitarian Consumption: An Integrated Cultural and Socio-economic Perspective," Global Economic Review. 35(2): 193206

Zeithaml, Valarie A. (1988). "Consumer Perceptions of Price, Quality, and Value: A Means-End Model and Synthesis of Evidence." Journal of Marketing, 52:2-22.

Zhan, Lingjing, and Yanqun He (2011), "Understanding luxury consumption in China: Consumer perceptions of bestknown brands," Journal of Business Research. 35(4): 706 